\title{
CULTIVATING ALPINES AT UTRECHT UNIVERSITY BOTANIC GARDEN
}

\author{
Wiert Nieuman ${ }^{l}$
}

The rock garden at the Utrecht University Botanic Garden was built between 1967 and 1976 and is considered to be the best of its type in the Netherlands. As well as traditional rock garden beds there are a number of special constructions such as raised beds, spheres and walls. This paper describes the history of the rock garden and the cultivation of the plants in it. The construction of the raised beds, spheres and walls are described along with some of the plants cultivated on them.

\section{INTRODUCTION}

The Utrecht University Botanic Garden has a large rock garden of approximately $4000 \mathrm{~m}^{2}$ which is considered to be the leading rock garden in the Netherlands. In the Netherlands every botanic garden has its own specialism and Utrecht's specialism is undoubtedly its rock and alpine garden plants.

\section{HISTORY OF THE ROCK GARDEN}

The University of Utrecht was built in the 1960's on the east side of the city. It was constructed on the site of a disused fortress which had been built on a man made island in the 19th Century. A moat of water called the 'fortress mould' surrounds the island and within the fortress itself there is a central or main area and two smaller depots with a separate arsenal for munitions. The rock garden is built on one of these depots which stand at $12 \mathrm{~m}$ high.

The rock garden was constructed between 1967 and 1976. In the Netherlands there are no natural mountains or rocky outcrops so the 2100 tons of stone required for its construction were imported from Belgium. Construction work was carried out during the winters of these years and horticultural work through the springs and summers. A small alpine house was built in 1995. Raised beds and troughs, situated beside the alpine house, were also constructed at this time from recycled, broken paving slabs. The most recently constructed areas are the peat walls and peat beds and this part of the garden has been restyled in the last two autumns.

The garden is divided into geographical areas with an area for cultivars and a scree bed with plants which experience drought conditions. The geographical areas represented are Asia, Europe, the Americas and the southern hemisphere. There is also an area dedicated to the 'Hochstauden'. This is the term used for large plants from the meadows and forest clearings in the valleys of European mountains.

${ }^{1}$ Wiert Nieuman is the Curator of the Utrecht University Botanic Garden.

Address: Utrecht University Botanic Garden, P.O. Box 80.162, Budapestlaan 17, 3508, Netherlands

Email: W.Nieuman@bio.uu.nl 


\section{CULTIVATION FROM SEED TO PLANT}

Like all botanic gardens Utrecht has a seed exchange scheme with other botanic gardens around the world. In this way they acquire many new introductions as seed. Some new introductions are purchased while others are donated as plants or seeds by members of the Dutch Rock Garden Society. Occasionally staff members take part in plant collecting expeditions.

Before the seed goes to the Head Gardener for sowing they are registered on the database and given their own database number. The packets of seeds and labels displaying this number are then passed on to garden staff. If possible, all cold germinating seeds are sown in autumn in a cold greenhouse. A layer of grit is placed in the bottom of a plastic pot which is then filled with normal sowing soil. The soil is compressed gently with the bottom of another pot. It is essential that the correct label be placed in the pot with the seed. Most seed is sown carefully by the Head Gardener and after sowing, a layer of sieved soil as thick as the depth of the seed is placed over the seed followed by a layer of fine grit and finally the pots are watered.

The pots are placed in a cold greenhouse for about three weeks after which they go in to a frame with Dutch lights. The lights are removed if it is snowing or there is a little bit of rain. In summer the lights are removed and a sheet of shading material is placed over them. Initially the pots are kept in a greenhouse in order to protect them from predation by mice. Once the seed has been thoroughly soaked and is beginning to germinate it seems to be less attractive to the mice. The pots stay outside until the seed germinates which can be up to two years. Seed that is received in spring is sown as soon as possible and handled in the same way. After germination the seedlings are pricked out and after a few weeks they are planted up. In spring and early summer, and sometimes in August, the plants are planted out in the garden. Normal potting soil with a neutral $\mathrm{pH}$ is used with, according to the species, added grit or sharp sand where necessary.

\section{SPECIAL CONSTRUCTIONS}

The lack of natural rocks in the Netherlands and the expense of imported stones means that the garden has to search for alternatives. One of these is concrete, especially from broken paving stones. From this material they have built three raised beds (Fig. 1), three spheres (Fig. 2) and some walls (Fig. 4).

\section{The raised beds}

The walls of the raised beds are made from broken roof tiles. In the Netherlands roof tiles used to be made with a curve in them and are called 'Old Dutch' roof tiles and are dark grey in colour. When broken in half lengthways the half roof tile that remains looks very like a piece of slate, so much so that many visitors believe them to be pieces of natural stone. Once the walls have been constructed the body of the raised bed is filled 


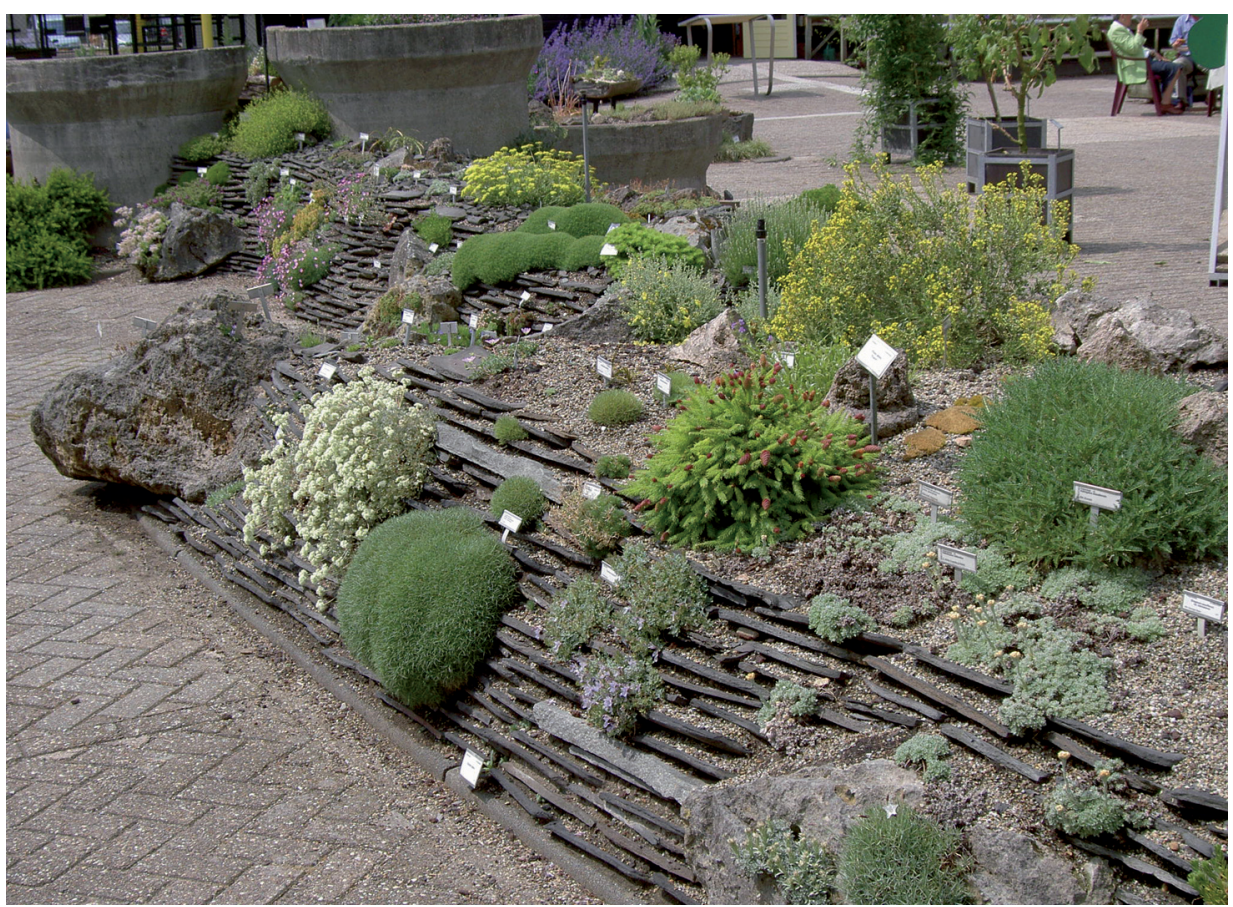

Fig. 1 The raised beds at the exit of the visitor centre. Photo: Wiert Nieuman.

with a mixture of garden soil, broken stones and pumice. In some places an old pig trough or a large piece of marl gives the beds a distinctive look.

These raised beds are used for difficult to cultivate rock plants. Species planted in this bed include Lewisia pygmaea, Leontopodium alpinum subsp. nivale, Astragalus angustifolius, Daphne arbuscula, Sedum sempervivoides, Androsace species, Vella spinosa, Gentiana acaulis, Dianthus erinaceus, Allium narcissiflorum, Bukiniczia cabulica, Edraianthus dinaricus, Degenia velebitica, Draba species, Eriogonum species, Physoplexis comosa, Potentilla nitida, Silene elisabethae, and Verbascum 'Letitia'. In late autumn these beds are covered with a roof of plastic so that the plants stay dry from December to the end of February. These beds are located at the entrance of the rock garden, beside the terrace at the exit from the visitor centre (Fig. 1). The volunteers who work in the visitor centre have a good view of the raised beds on the terrace, for the difficult to grow and expensive plants are attractive to thieves!

\section{The spheres}

In 1995-96 the garden experimented with recycled paving slabs, to build three spheres ranging in height from 1.5 to 2 metres and to do this they used the following technique. In the middle of the area where the sphere was to be constructed a metal pipe with a 


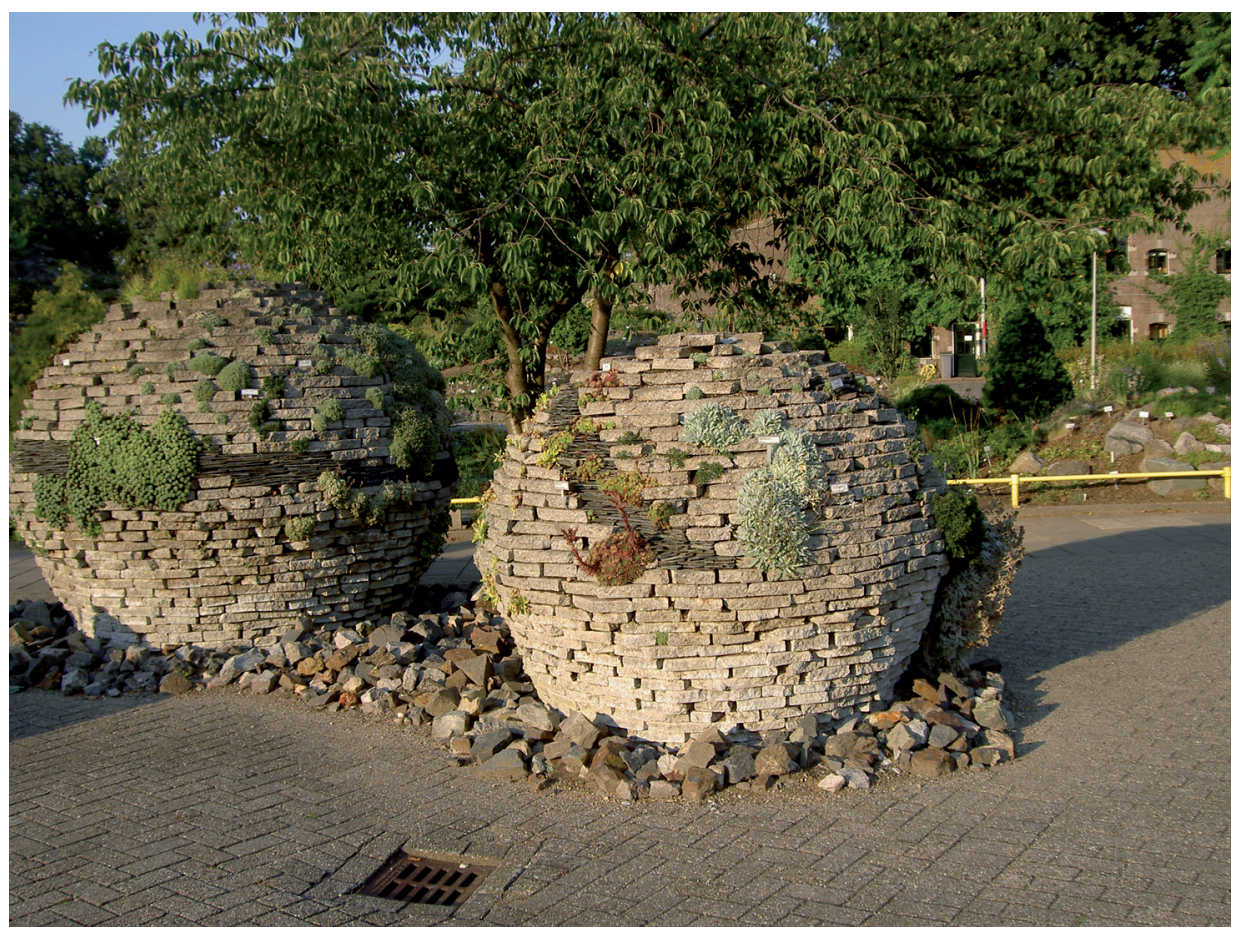

Fig. 2 The stone spheres. Photo: Wiert Nieuman.

diameter of about $5 \mathrm{~cm}$ was positioned. A water hose with a sprinkler attachment was then attached along this pipe to the top of the sphere. The metal pipe then acted as a fixed point for building the sphere. On the ground around the pipe a circle of broken paving stones was laid so that most of the space between the outside edge of the sphere and the pipe is filled with stone. Over these stones a thin layer of ordinary sandy garden soil was spread so that all the holes between them were filled. Another layer of stones was placed on top. This layer was about $2 \mathrm{~cm}$ wider than the previous layer. A measuring tape was used to ensure that the layers were making the correct spherical shape. It was important to fill every layer with the paving stones set closely next to each other and to fill the holes completely with sandy soil. In this way the layers were built up evenly and the sphere bulged out in a regular shape.

Once the sphere has reached half its intended height its diameter is measured with a wooden block. After constructing each layer staff measure around the growing sphere with the block which should reach from the edge to the pipe to the edge of the blocks all the way round. In this way a roughly ball-shaped stone sphere is constructed. For the best results, it is necessary to work accurately and to use a mason's stonecutter to shape broken paving stones.

When the sphere is complete it is planted up (Fig. 2). At first easily grown rock plants such as Sedum pachyclados, Armeria spp., and Sempervivum species and cultivars 


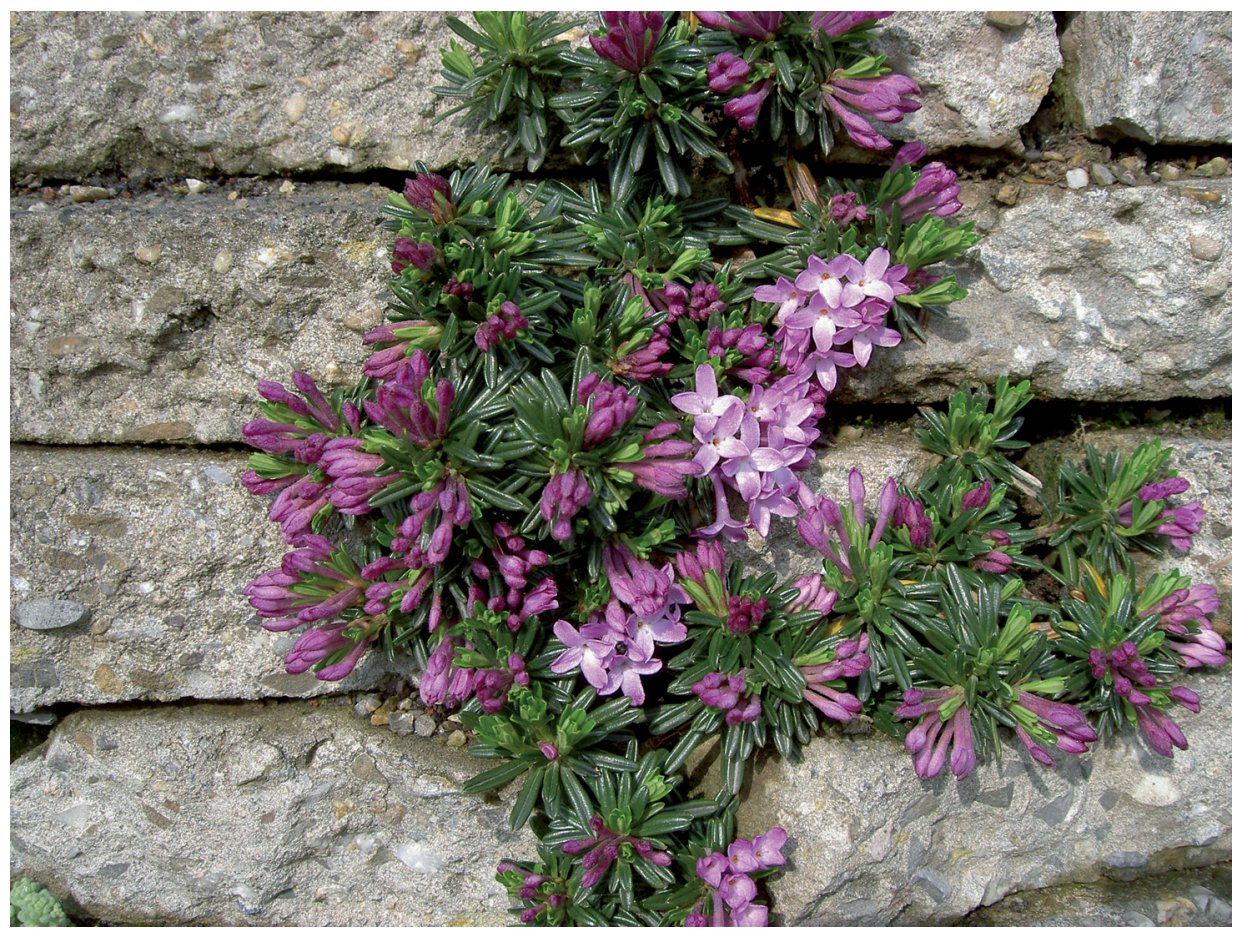

Fig. 3 Daphne arbuscula in the stone spheres. Photo: Wiert Nieuman.

and campanulas are used. Planting holes were made by using an old knife or screwdriver to prise apart the outer paving stones. This space was filled with soil and then the plants were carefully pushed into place and then the paving stones replaced.

At the moment the garden has three spheres of different sizes and they have now stopped planting them with very easy growers. Instead they are planted with Haberlea rhodopensis, on the shaded sides, Leontopodium alpinum subsp. nivale, Daphne arbuscula (Fig. 3), Veronica aphylla, Primula marginata, Primula auricula, and other genera such as Draba, Saxifraga, Dianthus, and Saponaria. Dionysia aretioides has also been planted on the lower part of the spheres. Several plants have flowered very well but die after two or three years and have to be replaced. A group of about 30 plants of Haberlea rhodopensis was planted in November 1995 and is still in full bloom every spring, testifying to the excellent growing conditions created by these spheres.

\section{The Walls}

The small alpine house is built against the soil wall of one of the depots. The outside walls of the alpine house are made of broken paving stones and broken concrete kerbstones of different thicknesses. Fig. 4 shows the effect of layering this material. The spaces 
between the stones create perfect planting holes for rock plants such as Saxifraga spp., Daphne cneorum and D. arbuscula, Gypsophila spp., Cerastium spp., Ramonda spp. and alpine ferns.

These walls are useful for difficult-to-grow rock plants because they always stay relatively dry yet the plants can get water and nutrients from the soil behind the wall. The design of these walls is a Dutch answer to the well known 'crevice gardens' created by alpine plant growers from the Czech Republic which are greatly admired by the author.

\section{GARDEN STAFF AND LABOUR}

The rock garden is staffed by the rock garden manager, a gardener and a volunteer who works one day

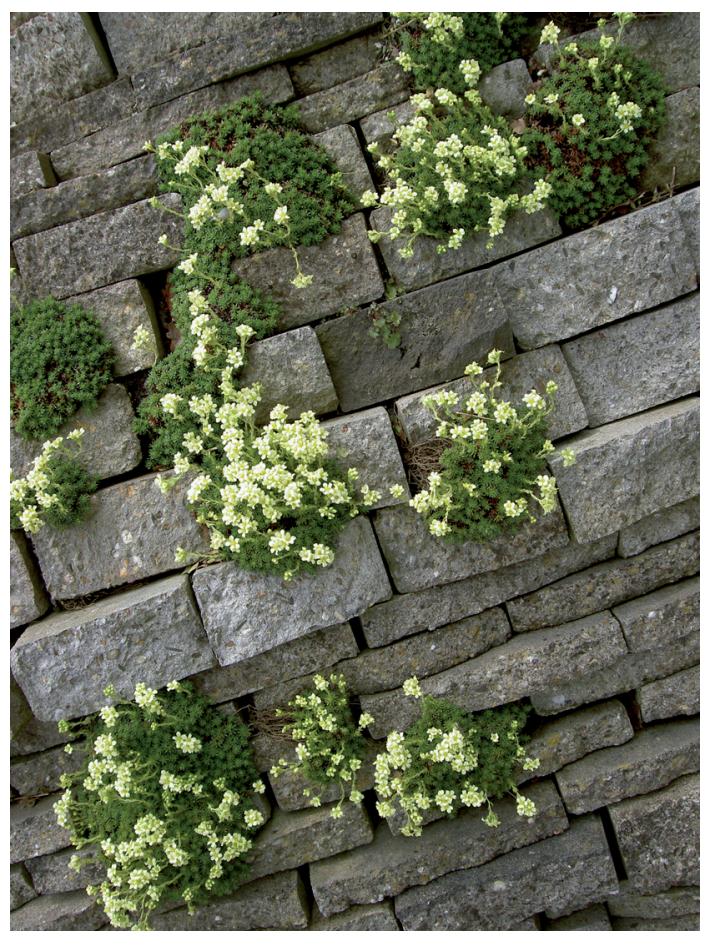

Fig. 4 Saxifraga sp. grows well in the stone walls. Photo: Wiert Nieuman. per week. In spring there are one or two students who also help, especially with the weeding. The rock garden manager and his staff also look after the nursery and the Theme Garden in which 18-20 different themes are displayed. Restyling and landscaping work is done between the months of September to March. 